\title{
Influence of Benzyladenine, Trinexapac-ethyl, or Uniconazole Applications on Height and Tillering of Six Ornamental Grasses
}

\author{
Sonali R. Padhye ${ }^{1}$ and Judith K. Groninger
}

AdDitional Index words. Carex, Cortaderia, Miscanthus, Mublenbergia, growth regulator, retardant

Summary. Three ornamental grasses, each within the families Cyperaceae [leatherleaf sedge (Carex buchananii), 'Frosted Curls' sedge (Carex comans), and 'Toffee Twist' sedge (Carex flagellifera)] and Poaceae ['Rosea' pampas grass (Cortaderia selloana), 'Gracillimus' miscanthus (Miscanthus sinensis), and muhly grass (Mublenbergia capillaris)], received two foliar sprays 2 weeks apart of benzyladenine (BA) at 500 or $1000 \mathrm{mg} \cdot \mathrm{L}^{-1}$, trinexapac-ethyl (TE) at $220 \mathrm{mg} \cdot \mathrm{L}^{-1}$, or uniconazole at 20 or $40 \mathrm{mg} \cdot \mathrm{L}^{-1}$. The influence of these spray applications on plant height and tiller number was assessed $0,2,4$, and 8 weeks after the initial treatment (WAIT). Benzyladenine applications did not suppress the height of leatherleaf sedge or 'Gracillimus' miscanthus, yet did suppress the height of the other ornamental grasses by $<\mathbf{1 5 \%}$ compared to the controls, depending on the concentration used and the time. Applications of BA increased tiller production only in 'Toffee Twist' sedge at 2 and 4 WAIT compared to the controls; however, at 8 WAIT, this increase was diminished. Depending on the species, uniconazole suppressed the height of the Cyperaceae grasses by $11 \%$ to $22 \%$ compared to the controls at 8 WAIT. In Poaceae species, uniconazole suppressed the height of only 'Rosea' pampas grass by up to $32 \%$ compared to the controls. Uniconazole applications did not increase the tillering of any ornamental grasses tested, except 'Toffee Twist' sedge at 8 WAIT. Within Cyperaceae, TE suppressed the height of only 'Toffee Twist' sedge compared to the controls, while TE effectively controlled the height of all Poaceae grasses. Based on the species and time, TE application elicited up to $37 \%$ height suppression compared to the controls of Poaceae grasses, while it did not influence the tiller number of any ornamental grasses in this study.

$\mathrm{O}$ rnamental grasses have gained increasing popularity not only in the landscapes, but they have also become prominent components in mixed containers (Cameron, 2004). Ornamental grasses comprise plants within Poaceae (grass family) and monocotyledonous grasslike plants within several families, including Cyperaceae (the sedge family), Juncaceae (the rush family), Restionaceae (the restio family), and Typhacea (the cattail family) (Darke, 1999). Many ornamental grasses are tall and vigorous during greenhouse or nursery production, hence suppressing plant height is necessary. Controlling the height of ornamental

Department of Environmental Horticulture, West Florida Research and Education Center, University of Florida, 5988 Highway 90, Building 4900, Milton, FL 32583

We gratefully acknowledge Fine Americas Inc. for financial support, Emerald Coast Growers for plant material donation, and Conrad Fafard Inc. for donation of the growing medium.

The use of trade names does not imply endorsement of the products named or criticism of similar ones not named.

${ }^{1}$ Corresponding author. E-mail: padhye@ufl.edu. grasses has multiple benefits, including avoiding container lodging, maintaining height proportional to the container to improve quality, and increasing transportation efficiency by accommodating the maximum number of containers per cart. Published information on height control of ornamental grasses using plant growth regulators (PGRs) is limited. Sellmer et al. (2001) reported that the height of pampas grass was controlled with substrate drenches of ancymidol, paclobutrazol, or uniconazole. The height of purple fountain grass (Pennisetum xadvena 'Rubrum') was controlled by spray applications of $50 \mathrm{mg} \cdot \mathrm{L}^{-1}$ ancymidol or paclobutrazol, $6000 \mathrm{mg} \cdot \mathrm{L}^{-1}$ chlormequat chloride, or $40 \mathrm{mg} \cdot \mathrm{L}^{-1}$ uniconazole (Wang et al., 2000). Uniconazole is a very active PGR that is effective on a wide range of species (Barrett, 2001), including pampas grass (Sellmer et al., 2001) and purple fountain grass (Wang et al., 2000). Uniconazole is a preferred PGR for vigorous species such as lily (Lilium spp.) and chrysanthemum (Chrysanthemum $\times$ morifolium) because it is effective at a 10- and 9-fold less concentration compared to paclobutrazol, respectively (Barrett, 2001). To our knowledge, the efficacy of uniconazole on height control of a wide range of vigorous ornamental grasses is unknown. Trinexapac-ethyl (TE) effectively controlled the height of several species of turfgrass (Fagerness and Penner, 1998; McCullough et al., 2007). However, the efficacy of TE on the height regulation of ornamental grasses remains unknown. Commercial growers are interested in researchbased information on the efficacy of PGRs for the height control of ornamental grasses (D. Dagen, personal communication).

Crop production time for ornamental grasses consists of the time required for sufficient tiller production to fill containers. Therefore, promoting tillering by applications of PGRs can be of great significance. Additionally, increased tillering can improve propagule yield of ornamental grasses propagated by divisions. Benzyladenine (BA) promoted branching of many dicotyledonous species (Carpenter, 1975; Emongor et al., 2004; Latimer and Freeborn, 2008; Little, 1985; Padhye et al., 2008 ) and hosta (Hosta spp.), a monocotyledonous species (Keever, 1994), and TE applications increased tillering in turfgrasses (Erwin and Koski, 1998; Erwin et al., 2002). To our knowledge, there is no published information available on the influence of BA or TE on the tillering of ornamental grasses.

\begin{tabular}{llll}
\hline $\begin{array}{l}\text { Units } \\
\begin{array}{l}\text { To convert U.S. to SI, } \\
\text { multiply by }\end{array}\end{array}$ & U.S. unit & SI unit & $\begin{array}{l}\text { To convert SI to U.S., } \\
\text { multiply by }\end{array}$ \\
\hline 29.5735 & $\mathrm{fl} \mathrm{oz}$ & $\mathrm{mL}$ & 0.0338 \\
3.7854 & $\mathrm{gal}$ & $\mathrm{L}$ & 0.2642 \\
0.4075 & $\mathrm{gal} / 100 \mathrm{ft}^{2}$ & $\mathrm{~L} \cdot \mathrm{m}^{-2}$ & 2.4542 \\
2.54 & inch $(\mathrm{es})$ & $\mathrm{cm}$ & 0.3937 \\
1 & $\mathrm{ppm}$ & $\mathrm{mg} \cdot \mathrm{L}^{-1}$ & 1 \\
0.001 & $\mathrm{ppm}$ & $\mathrm{mL} \cdot \mathrm{L}^{-1}$ & 1000 \\
$\left({ }^{\circ} \mathrm{F}-32\right) \div 1.8$ & ${ }^{\circ} \mathrm{F}$ & ${ }^{\circ} \mathrm{C}$ & $\left(1.8 \times{ }^{\circ} \mathrm{C}\right)+32$
\end{tabular}


The objective of this study was to quantify the influence of foliar spray applications of BA, TE, or uniconazole on height control and tillering of ornamental grasses. For this study, we used three commercially important ornamental grasses, each within $\mathrm{Cy}$ peraceae (leatherleaf sedge, 'Frosted Curls' sedge, and 'Toffee Twist' sedge) and Poaceae ('Rosea' pampas grass, 'Gracillimus' miscanthus, and muhly grass).

\section{Materials and methods}

Plant growth. On 24 Jun. 2008, rooted liners of leatherleaf sedge, 'Frosted Curls' sedge, 'Toffee Twist' sedge (50-cell size, $65-\mathrm{mL}$ volume), 'Rosea' pampas grass (36cell size, $100-\mathrm{mL}$ volume), 'Gracillimus' miscanthus, and muhly grass (72-cell size, 62-mL volume) were received from a commercial grower (Emerald Coast Growers, Pensacola, FL). Plants were transplanted into 6-inch-diameter plastic containers (0.72-gal volume) containing a commercial soilless medium (Fafard 3B; Conrad Fafard, Agawam, MA) on the day of receipt. Plants were grown in a polycarbonate greenhouse under natural daylengths. The average daily temperature in the greenhouse was $25 \pm 2.9^{\circ} \mathrm{C}$ as measured by a weather station (Watchdog Mini Station model 2475; Spectrum Technologies, Plainfield, IL). When necessary, plants were fertigated with $200 \mathrm{mg} \cdot \mathrm{L}^{-1}$ nitrogen; $24.9 \mathrm{mg} \cdot \mathrm{L}^{-1}$ phosphorus; 166 $\mathrm{mg} \cdot \mathrm{L}^{-1}$ potassium; $71.4 \mathrm{mg} \cdot \mathrm{L}^{-1} \mathrm{cal}-$ cium; $28.6 \mathrm{mg} \cdot \mathrm{L}^{-1}$ magnesium; 1.4 $\mathrm{mg} \cdot \mathrm{L}^{-1}$ iron; $0.71 \mathrm{mg} \cdot \mathrm{L}^{-1}$ copper, manganese, and zinc; $0.3 \mathrm{mg} \cdot \mathrm{L}^{-1}$ boron, and $0.01 \mathrm{mg} \cdot \mathrm{L}^{-1}$ molybdenum (Total Gro; SDT Industries, Winnsboro, LA).

Plant growth regulator TREATMENTS. The experiment was initiated by applying a foliar spray of one of three PGRs at five possible concentrations in the following combinations: 500 or $1000 \mathrm{mg} \cdot \mathrm{L}^{-1} \mathrm{BA}$ (Configure; Fine Americas, Walnut Creek, CA), $220 \mathrm{mg} \cdot \mathrm{L}^{-1}$ TE (Primo Maxx; Syngenta Crop Protection, Greensboro, NC), or 20 or $40 \mathrm{mg} \cdot \mathrm{L}^{-1}$ uniconazole (Concise, Fine Americas). PGR dilutions were made using deionized water containing a surfactant at $1.25 \mathrm{~mL} \cdot \mathrm{L}^{-1}$ (CapSil; Aquatrols, Paulsboro, NJ) and were applied using a pressurized hand sprayer (Solo Spritzer 415S; Solo, Newport News,
VA). The PGR sprays were applied twice at 2-week intervals to 10 plants per treatment at $0.5 \mathrm{gal} / 100 \mathrm{ft}^{2}$. Additionally, a nontreated control treatment was maintained. Three weeks after transplant, the first PGR application was made on the sedges, while the Poaceae grasses were first sprayed 4 weeks after transplant. Following PGR applications, plants were allowed to air dry and were then arbitrarily placed on greenhouse benches.

DATA COLLECTION AND ANALYSIS. Plant height (from medium surface to the longest extended tip of grass) and the number of tillers were recorded at $0,2,4$, and 8 weeks after the initial treatment (WAIT). The experimental units were arranged in a completely randomized design. Height and tiller number data were analyzed using PROC MIXED in SAS (version 9.1; SAS Institute, Cary, NC). PROC MIXED and pairwise treatment comparisons were made using Tukey's honestly significant difference test at $P \leq 0.05$. Data for height and tiller number increase as a function of time were fitted to quadratic polynomial models using SigmaPlot (version 8.02; SPSS, Chicago).

\section{Results and discussion}

Plant height. The influence of PGRs on plant growth is dynamic and is not only species-specific, but also depends on the PGR used, the concentration and method of application, and numerous environmental and cultural factors (Barrett, 2001). In this study, the height control and tillering responses of the six ornamental grasses varied; however, there were some trends specific to the grasses within Cyperaceae versus Poaceae. Over time, plant height of nontreated controls of the ornamental grasses increased and fit quadratic polynomial models $\left(r^{2}=0.34-0.94\right.$; Fig. 1 , A-F). The height of controls of leatherleaf sedge, 'Frosted Curls', and 'Toffee Twist' sedge increased from 65 to $81 \mathrm{~cm}, 37$ to $45 \mathrm{~cm}$, and 56 to $83 \mathrm{~cm}$, respectively, at 8 WAIT (Fig. 1, A-C). Benzyladenine, TE, or uniconazole applications did not suppress the height of these three Cyperaceae grasses at 2 and 4 WAIT compared to the controls (data not shown). At 8 WAIT, leatherleaf sedge treated with $20 \mathrm{mg} \cdot \mathrm{L}^{-1}$ uniconazole was $16 \%$ shorter compared to the controls (Fig. 1A). The height of
'Frosted Curls' sedge was similarly suppressed by $500 \mathrm{mg} \cdot \mathrm{L}^{-1} \mathrm{BA}$ or either concentration of uniconazole by up to $13 \%$ compared to the controls at 8 WAIT (Fig. 1B). Benzyladenine at $1000 \mathrm{mg} \cdot \mathrm{L}^{-1}, \mathrm{TE}$, or either concentration of uniconazole suppressed the height of 'Toffee Twist' sedge by $12 \%$ to $24 \%$ compared to the controls at 8 WAIT (Fig. 1C).

At 8 WAIT, the height of 'Rosea' pampas grass, 'Gracillimus' miscanthus, and muhly grass controls increased from 73 to $167 \mathrm{~cm}, 64$ to $124 \mathrm{~cm}$, and 68 to $107 \mathrm{~cm}$, respectively (Fig. 1, D-F). Only TE controlled the height of 'Rosea' pampas grass at 2 WAIT compared to the controls by $13 \%$ (Fig. 1D). At 4 WAIT, 'Rosea' pampas grass treated with TE or either concentration of uniconazole was shorter by up to $23 \%$ compared to the controls. All treatments except $500 \mathrm{mg} \cdot \mathrm{L}^{-1}$ BA effectively suppressed the height of 'Rosea' pampas grass at 8 WAIT compared to the controls with the least height suppression by 1000 $\mathrm{mg} \cdot \mathrm{L}^{-1} \mathrm{BA}(12 \%)$ and greater height control by uniconazole (up to $32 \%$ ) and TE (37\%). The height of 'Gracillimus' miscanthus was not controlled by BA or uniconazole for up to 8 WAIT (data not shown). However, TE suppressed the height of 'Gracillimus' miscanthus at 2,4 , and 8 WAIT by $17 \%, 27 \%$, and $23 \%$ compared to the controls, respectively (Fig. IE). No PGR suppressed the height of muhly grass at 2 WAIT (data not shown). However, $1000 \mathrm{mg} \cdot \mathrm{L}^{-1} \mathrm{BA}$ or TE provided similar height control at 4 WAIT (up to $18 \%$ compared to the controls) (Fig. 1F). At 8 WAIT, TE provided greater height control of muhly grass compared to 1000 $\mathrm{mg} \cdot \mathrm{L}^{-1} \mathrm{BA}$ (35\% vs. $14 \%$ compared to the controls).

Based on the species, BA application can inhibit or promote stem elongation. For example, BA applications elicited varying degrees of height suppression in seedlings of fraser fir [ Abies fraseri (Bryan and Seiler, 1991)] and happy tree [Camptotheca acuminate ( $\mathrm{Li}$ and Liu, 2003)]. Conversely, BA promoted stem elongation in chamomile [Matricaria chamomilla (Emongor et al., 2004)]. In this study, BA applications did not promote height increase in any ornamental grasses and did not suppress the height of muhly grass at 2 WAIT, 'Frosted Curls' 


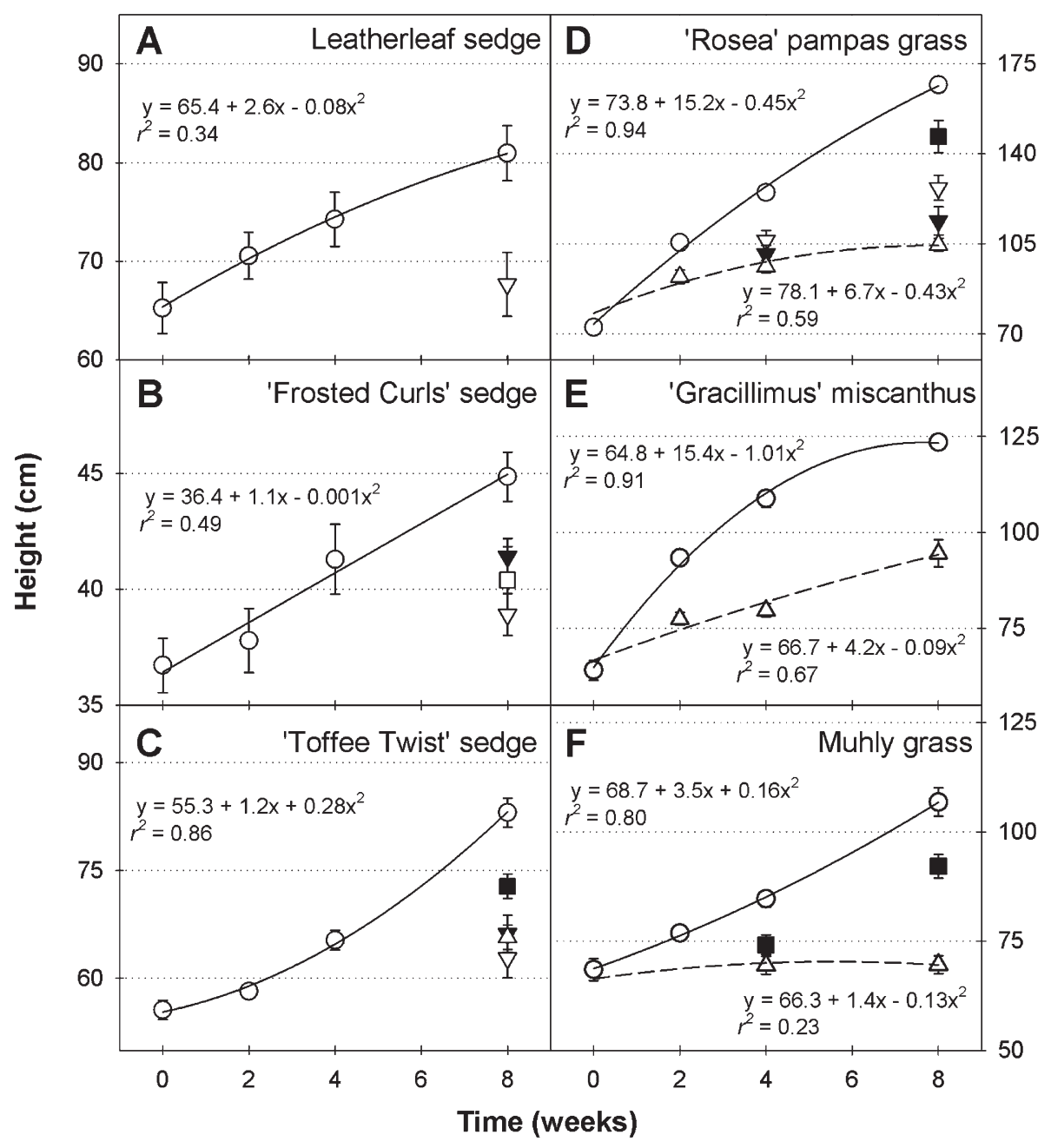

Fig. 1. Increase in plant height (from medium surface to the longest extended tip of grass) over time of nonsprayed controls ( $\bigcirc$ ) of leatherleaf sedge (A), 'Frosted Curls' sedge (B), 'Toffee Twist' sedge (C), 'Rosea' pampas grass (D), 'Gracillimus' miscanthus (E), and muhly grass (F). Plants received a foliar spray of $500(\square)$ or $1000(\square) \mathrm{mg} \cdot \mathrm{L}^{-1}$ (ppm) benzyladenine, $220 \mathrm{mg} \cdot \mathrm{L}^{-1}$ trinexapac-ethyl $(\triangle)$, or $20(\nabla)$ or $40(\nabla) \mathrm{mg} \cdot \mathrm{L}^{-1}$ uniconazole at the initiation of experiment and a second spray 2 weeks thereafter. Only treated plants that were significantly shorter compared to the controls are included. Each point represents mean \pm SE of 10 replicates. The solid and broken lines represent regression lines generated for the entire population data using quadratic polynomial models for controls and treated plants that were significantly shorter compared to the controls, respectively $(1 \mathrm{~cm}=0.3937 \mathrm{inch})$.

sedge, 'Toffee Twist' sedge, or 'Rosea' pampas grass at 4 WAIT, or leatherleaf sedge or 'Gracillimus' miscanthus at 8 WAIT. At 8 WAIT, $500 \mathrm{mg} \cdot \mathrm{L}^{-1}$ BA suppressed the height of 'Frosted Curls' sedge by $10 \%$, and $1000 \mathrm{mg} \cdot \mathrm{L}^{-1}$ BA-treated 'Toffee Twist' sedge, 'Rosea' pampas grass, and muhly grass were up to $14 \%$ shorter compared to the controls. Based on these results, the influence of BA on height suppression of ornamental grasses was low $(<15 \%)$, inconsistent, and speciesspecific.

Uniconazole has been effective in controlling the height of almost all floriculture crops (Barrett, 2001), including pampas grass when used as a drench (Sellmer et al., 2001) and purple fountain grass when used as a foliar spray (Wang et al., 2000). In this study, uniconazole was ineffective in providing height control of the three Cyperaceae grasses at 2 and 4 WAIT; however, at 8 WAIT, uniconazole was effective. At 8 WAIT, uniconazole at $20 \mathrm{mg} \cdot \mathrm{L}^{-1}$ suppressed the height of leatherleaf sedge, while $40 \mathrm{mg} \cdot \mathrm{L}^{-1}$ uniconazole did not. Although unexpected, this inconsistency in height control between uniconazole concentrations is not unprecedented. Blanchard and Runkle (2007) reported inconsistent height control of 'Rapunzel Red' verbena (Verbena $\times$ hybrida) by uniconazole liner dip at $2 \mathrm{mg} \cdot \mathrm{L}^{-1}$ compared to $4 \mathrm{mg} \cdot \mathrm{L}^{-1}$ and nontreated controls.
The authors concluded that the height control data from $2 \mathrm{mg} \cdot \mathrm{L}^{-1}$ uniconazole were outliers. Overall, our results indicate that uniconazole controlled the height of the Cyperaceae grasses by up to $22 \%$ at 8 WAIT, depending on the species. If additional height control is desired, higher uniconazole concentrations, multiple spray applications, or drenches may be necessary. However, the possibility of uniconazole persistence decreasing growth after landscape transplanting should be considered. Among the ornamental grasses within Poaceae, uniconazole controlled the height of only 'Rosea' pampas grass, with both concentrations similarly suppressing height by up to $19 \%$ and 
$32 \%$ compared to the controls at 4 and 8 WAIT, respectively.

Trinexapac-ethyl effectively suppressed the height of many monocotyledonous species within Poaceae, including turfgrasses (Fagerness and Penner, 1998; McCullough et al., 2007). Trinexapac-ethyl also controlled the height of chrysanthemum, while it did not suppress height of several other dicotyledonous species (Gardner and Metzger, 2005). In this study, TE did not suppress the height of two Cyperaceae grasses, leatherleaf sedge and 'Frosted Curls' sedge. The height of 'Toffee Twist' sedge was suppressed by TE only at 8 WAIT. Overall, TE was the most effective PGR for controlling the height of the three Poaceae grasses and it suppressed the height of 'Rosea' pampas grass and 'Gracillimus' miscanthus for up to 8 WAIT and muhly grass at 4 and 8 WAIT. 'Rosea' pampas grass treated with TE was $37 \%$ shorter compared to the controls at 8 WAIT, and in some bedding and potted plants, $>30 \%$ height suppression may be considered excessive. 'Rosea' pampas grass grown in $15-\mathrm{cm}$-diameter containers was $105 \mathrm{~cm}$ at 8 WAIT and therefore would have required additional height control to obtain the appropriate height for the containers used. Similarly, at 8 WAIT, TE-treated 'Gracillimus' miscanthus was $95 \mathrm{~cm}$ and would also have benefited from additional height control. Before using additional TE applications, possible persistence of TE eliciting slower growth after landscape transplanting should be evaluated. Trinexapac-ethyl suppressed the height of muhly grass by $35 \%$ compared to the controls at 8 WAIT, resulting in $70-\mathrm{cm}$-tall plants that were of a commercially desirable height proportional to the containers used (personal observation).

Tiller number. Increased tiller production of ornamental grasses can reduce crop time and increase the number of propagules when grasses are propagated by divisions and it is therefore of significance to the industry. The number of tillers produced by the six ornamental grasses increased with time and fit quadratic polynomial models $\left(r^{2}=0.29-0.96\right.$; Fig. 2, A-F). The tiller number of controls of leatherleaf sedge, 'Frosted Curls' sedge, and 'Toffee Twist' sedge increased from 17 to 61,19 to 190 , and 24 to 86 , respectively at 8 WAIT (Fig. 2, A-C). Also, at 8 WAIT, the tiller number of 'Rosea' pampas grass, 'Gracillimus' miscanthus, and muhly grass increased from 3 to 6,43 to 82 , and 25 to 131 , respectively (Fig. 2, D-F). Benzyladenine, TE, or uniconazole applications did not influence the tiller number of leatherleaf sedge, 'Rosea' pampas grass, 'Gracillimus' miscanthus, and muhly grass compared to the controls at 8 WAIT (data not shown). At the initiation of treatments, 'Frosted Curls' sedge to be treated with either concentration of BA or uniconazole had $37 \%$ to $44 \%$ more tillers compared to the controls, indicating variability in the starting material (Fig. 2B). However, all PGR-treated and control plants of 'Frosted Curls' sedge had similar number of tillers at 2 WAIT (data not shown). 'Frosted Curls' sedge treated with 20 or $40 \mathrm{mg} \cdot \mathrm{L}^{-1}$ uniconazole had fewer tillers compared to the controls at 4 or 8 WAIT, respectively. Benzyladenine at $\mathbf{5 0 0}$ or $\mathbf{1 0 0 0}$ $\mathrm{mg} \cdot \mathrm{L}^{-1}$ significantly increased the tiller number of 'Toffee Twist' sedge compared to the controls by up to $25 \%$ at 2 and 4 WAIT and there was no difference between the tiller production efficacy of the two concentrations (Fig. 2C). However, at 8 WAIT, BA-treated plants and controls had a similar number of tillers. At 8 WAIT, 'Toffee Twist' sedge treated with $20 \mathrm{mg} \cdot \mathrm{L}^{-1}$ uniconazole had $51 \%$ more tillers compared to the controls.

Benzyladenine is marketed and typically commercially used as a PGR to promote lateral branching. This promotion of branching after BA applications has been reported in several species, including balsam fir Christmas tree [Abies balsamea (Little, 1985)], chamomile (Emongor et al., 2004), cone flower [Echinacea purpurea (Latimer and Freeborn, 2008)], hosta (Keever, 1994), poinsettia [Euphorbia pulcherrima (Padhye et al., 2008)], and rose [Rosa spp. (Carpenter, 1975)]. However, in this study, BA applications at 500 or 1000 $\mathrm{mg} \cdot \mathrm{L}^{-1}$ did not increase tillering of the ornamental grasses compared to the controls, except in 'Toffee Twist' sedge. The effective concentration of $\mathrm{BA}$ for promotion of branching is species-dependent. For example, the optimum concentration of a single spray application of BA to promote branching of poinsettia was 50 $\mathrm{mg} \cdot \mathrm{L}^{-1}$ (Padhye et al., 2008) and that for hosta was 2000 to $3000 \mathrm{mg} \cdot \mathrm{L}^{-1}$ (Keever, 1994). The two spray applications of up to $1000 \mathrm{mg} \cdot \mathrm{L}^{-1}$ of $\mathrm{BA}$ used in this study were likely within the range of reported effective BA concentrations for increased branching. Therefore, our results suggest that $\mathrm{BA}$ is ineffective for promoting tillering of the ornamental grasses tested in this study except for 'Toffee Twist' sedge. In 'Toffee Twist' sedge, BA increased tiller production only at 2 and 4 WAIT and this increase in tiller number was diminished at 8 WAIT. Therefore, BA application for increased tiller production in 'Toffee Twist' sedge may not be commercially viable.

Uniconazole applications did not increase tiller number of any ornamental grasses tested except for 'Toffee Twist' at 8 WAIT and because this increased tiller production was an anomaly, additional studies investigating it further are warranted. In this study, uniconazole did not decrease tiller production in other ornamental grasses besides 'Frosted Curls'. 'Frosted Curls' sedge treated with 20 or $40 \mathrm{mg} \cdot \mathrm{L}^{-1}$ uniconazole had fewer tillers compared to the controls at 4 or 8 WAIT, respectively. However, this decreased tiller production in uniconazole-treated 'Frosted Curls' sedge was inconsistent over time and over concentrations and, therefore, it cannot be explained. Trinexapac-ethyl applications increased tillering in turf species (Erwin and Koski, 1998; Erwin et al., 2002). However, TE applications did not increase the number of tillers in the six ornamental grasses tested in this study.

\section{Conclusion}

Our results indicate that PGRs can successfully control the height of the six ornamental grasses tested in this study; however, no PGRs tested consistently improved the tillering of these grasses throughout the production. At the concentrations tested, uniconazole was effective in controlling the height of the Cyperaceae grasses at 8 WAIT. Overall, TE was the most effective PGR for controlling the height of the Poaceae grasses tested. Due to low $(<15 \%)$, inconsistent, and species-specific height 


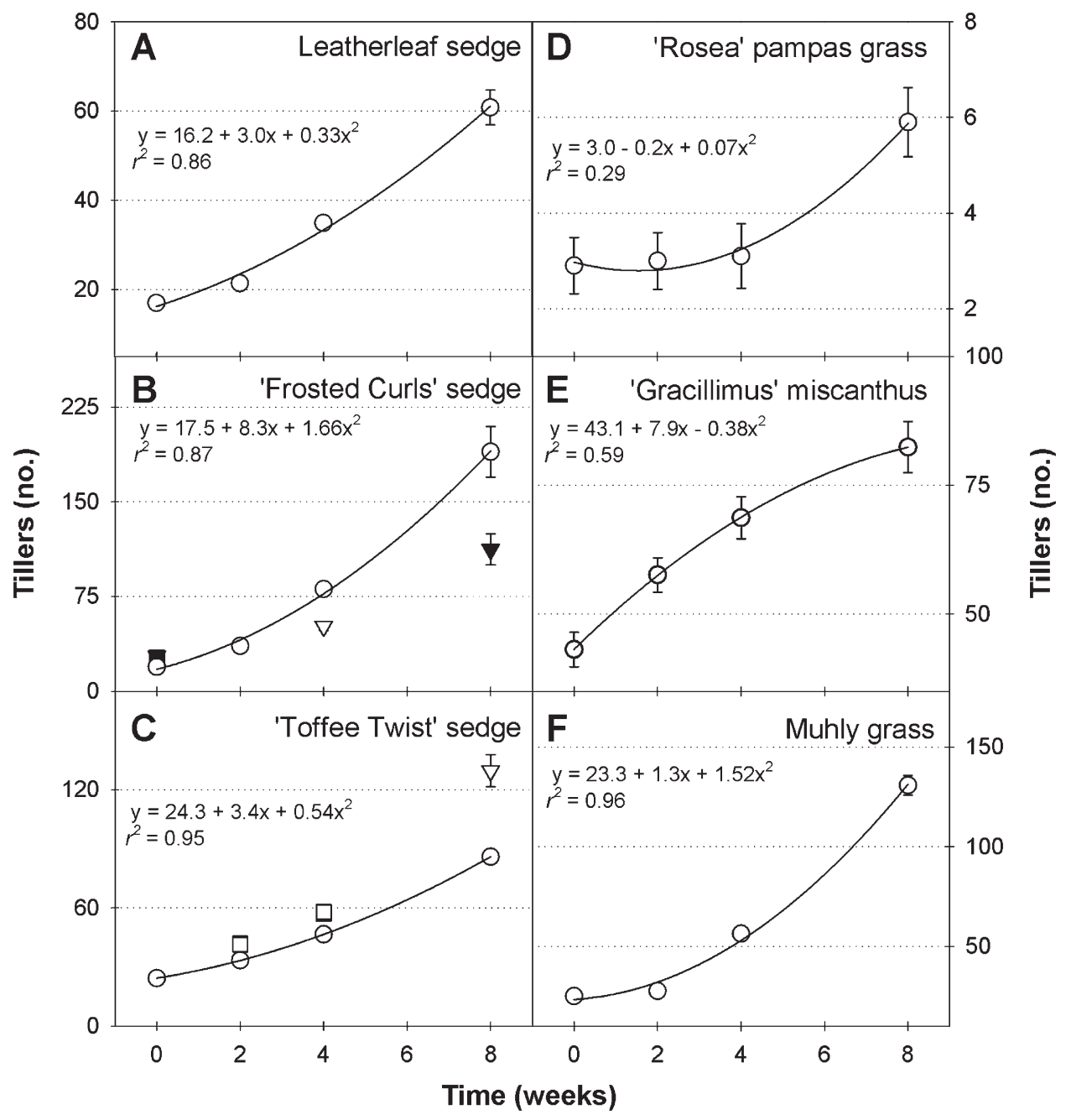

Fig. 2. Increase in tiller number over time of nonsprayed controls $(O)$ of leatherleaf sedge (A), 'Frosted Curls' sedge (B), 'Toffee Twist' sedge (C), 'Rosea' pampas grass (D), 'Gracillimus' miscanthus (E), and muhly grass (F). Plants received a foliar spray of $500(\square)$ or $1000(\square) \mathrm{mg} \cdot \mathrm{L}^{-1}(\mathrm{ppm})$ benzyladenine, $220 \mathrm{mg} \cdot \mathrm{L}^{-1}$ trinexapac-ethyl $(\triangle)$, or $20(\nabla)$ or $40(\nabla) \mathrm{mg} \cdot \mathrm{L}^{-1} \mathrm{uniconazole}$ at the initiation of experiment and a second spray 2 weeks thereafter. Only treated plants with a significantly different tiller number than controls are included. Each point represents mean \pm SE of 10 replicates. The solid and broken lines represent regression lines generated for the entire population data using quadratic polynomial models for controls and treated plants that were significantly shorter compared to the controls, respectively.

suppression, the use of BA for height regulation of ornamental grasses may not be commercially adaptable. Additionally, although BA treatments increased the tillering of 'Toffee Twist' sedge at 2 and 4 WAIT, this increase was diminished at 8 WAIT. Therefore, the additional BA applications may not be necessary if 'Toffee Twist' sedge is grown for 8 WAIT. As height control by PGRs depends on a plethora of cultural and environmental factors, growers should conduct their own trials to determine the appropriate PGR concentrations for their production systems. When combined with graphical tracking as a decision support tool (Runkle, 2007), uniconazole or TE can provide timely and precise height control of Cyperaceae and Poaceae grasses tested, respectively.

\section{Literature cited}

Barrett, J. 2001. Mechanisms of action, p. 32-41. In: M.L. Gaston, P.S. Konjoian, L.A. Kunkle, and M.F. Wilt (eds.). Tips on regulating growth of floriculture crops. Ohio Florists' Assn. Serv., Columbus, $\mathrm{OH}$.

Blanchard, M.G. and E.S. Runkle. 2007. Dipping bedding plant liners in paclobutrazol or uniconazole inhibits subsequent stem extension. HortTechnology 17: 178-182.

Bryan, J.A. and J.R. Seiler. 1991. Accelerating fraser fir seedling growth with benzylaminopurine sprays. HortScience 26:389-390

Cameron, A. 2004. Ornamental grasses: A new wave in floriculture crops. Greenhouse Product News 14:50-54.

Carpenter, W.J. 1975. Foam sprays of plant growth regulating chemicals on rose shoot development at cutback. HortScience 10:605-606.

Darke, R. 1999. The color encyclopedia of ornamental grasses. Timber Press, Portland, OR.

Emongor, V.E., C.M.M. Mutunga, and J.A. Chweya. 2004. Effect of benzyladenine on growth and flower yield of chamomile plants. Trop. Agr. 81:1-6.

Erwin, E.H. and A.J. Koski. 1998. Growth responses of Lolium perenne L. 


\section{Research Reports}

to trinexapac-ethyl. HortScience 33: 1200-1202.

Erwin, E.H., C.H. Ok, B.S. Fresenburg, and J.H. Dunn. 2002. Trinexapac-ethyl restricts shoot growth and prolongs stand density of 'Meyer' zoysiagrass fairway under shade. HortScience 37:502-505.

Gardner, D.S. and J.D. Metzger. 2005. Use of the trinexapac-ethyl for growth regulation of chrysanthemum (Dendranthema $\times$ grandiflora). HortScience 40: 670-674.

Fagerness, M.J. and D. Penner. 1998. Evaluation of V-10029 and trinexapacethyl for annual bluegrass seedhead suppression and growth regulation of five cool-season turfgrass species. Weed Technol. 12:436-440.

Keever, G.J. 1994. BA-induced offset formation in hosta. J. Environ. Hort. 12: 36-39.
Latimer, J. and J. Freeborn. 2008 Enhance branching of echinacea with PGRs. Greenhouse Product News 18: 24-28.

Li, A. and Z. Liu. 2003. Effects of benzyladenine and naphthalene acetic acid on growth and camptothecin accumulation in Camptotheca acuminate seedlings. J. Plant Growth Regul. 22:205-216.

Little, C.H.A. 1985. Increasing lateral shoot production in balsam fir Christmas trees with cytokinin application. HortScience 20:713-714.

McCullough, P.E., H. Liu, L.B. McCarty, and J.E. Toler. 2007. Trinexapac-ethyl application regimens influence growth, quality, and performance of bermudagrass and creeping bentgrass putting greens. Crop Sci. 47:2138-2144.

Padhye, S., E. Runkle, M. Olrich, and L. Reinbold. 2008. Improving branching and postharvest quality. Greenhouse Product News 8:36-42.

Runkle, E. 2007. Technically speaking: Graphical tracking. Greenhouse Product News 17:98.

Sellmer, J.C., C.R. Adkins, I. McCall, and B.E. Whipker. 2001. Pampas grass responses to ancymidol, paclobutrazol, and uniconazole substrate drenches. HortTechnology 11:216-219.

Wang, S., W. Carlson, H. Gao, A. Cameron, and R.D. Heins. 2000. Cultivating purple fountain grass, p. 104-105. In: R.D. Heins, A. Cameron, and W. Carlson (eds.). Firing up perennials, 2000 ed. Meister Media, Willoughby, $\mathrm{OH}$ 